Volume and Issues Obtainable at Center for Sustainability Research and Consultancy

Journal of Accounting and Finance in Emerging Economies

ISSN: 2519-0318 \& ISSN (E): 2518-8488

Volume 7: Issue 2 June 2021

Journal homepage: www.publishing.globalcsrc.org/jafee

\title{
Impact of Entrepreneurship Competencies on Entrepreneurship Motivation among Pakistani Students: Entrepreneurship Education as Moderation
}

*Gohar Mahmood, College of Commerce, Government College University, Faisalabad, Pakistan Sadia Munir, Government College Women University, Faisalabad, Pakistan

Sidra Ghulam Rasool, Government College Women University, Faisalabad, Pakistan

Rubab Anum, Government College Women University, Faisalabad, Pakistan

*Corresponding author's email: goharmahmood@gcuf.edu.pk

\begin{tabular}{l}
\hline ARTICLE DETAILS \\
History \\
Revised format: May 2021 \\
Available Online: Jun 2021
\end{tabular}

\section{Keywords}

Entrepreneurship

Competencies,

Entrepreneurship

Education,

Entrepreneurship

Motivation,

Pakistan.

JEL Classification

M1, M12

\begin{abstract}
Purpose: The purpose of this study is to investigate the relationship between entrepreneurship competencies and entrepreneurship motivation through moderating role of entrepreneurial education in the university students of (Punjab) Pakistan. This study provides a comprehensive answer to the research question of how entrepreneurship competencies and entrepreneurial education effects the entrepreneurship motivation among university students.

Design/Methodology/Approach: A survey questionnaire was used to collect data from faculty of management sciences students of different departments at various campuses in (Punjab) Pakistan. Factor analysis, reliability, and regression and correlation analysis was the techniques to analyze the links between the study variables.
\end{abstract}

Findings: There is a positive significant impact of entrepreneurship competencies on entrepreneurship motivation while entrepreneurship education as a moderator.

Implications/Originality/Value: At the last, this paper also presents some implications, limitations and suggestions for future research.

(C) 2021 The authors, under a Creative Commons Attribution-

NonCommercial 4.0

Recommended citation: Mahmood, G., Munir, S., Rasool, S. G. and Anum, R. (2021). Impact of Entrepreneurship Competencies on Entrepreneurship Motivation among Pakistani Students: Entrepreneurship Education as Moderation. Journal of Accounting and Finance in Emerging Economies, 7 (2), 497-510.

\section{Introduction}

The development of an entrepreneurial culture is not always smooth and steady; sometimes it faces the challenges of low productivity, and higher rate of unemployment. Entrepreneurship expands the capabilities of exploring opportunities in an environment marked by dynamics and uncertainty. Entrepreneurship education has been introduced significantly in most developed 
nations to support entrepreneurs around the globe to have required familiarizing a number of programs in educational institutes (Bouncken, 2020). Entrepreneurs are those who running, operating and assuming risk to start up business venture and people who operating is to perform new blends called enterprises and are the key motivators in social and economic expansion (Cullin, 2020). Entrepreneurship concerns the environment conditioning opportunity, the procedure of determining opportunity, exploitation of opportunity, assessment and the individual decision maker who do these things (Galvin, 2020). Entrepreneurs are that who utilize their resources and knowledge to develop or generate new business opportunities, which are energetically, participates in managing their businesses (Cazurra, 2020).

Entrepreneurship Competencies may be well-defined as integrated and combined components of skills, attitudes and knowledge and through training, experience and coaching these competencies are attainable, changeable and learnable (Hilson, 2020). There are many authors who believed that entrepreneurs may be successful in an analytical and behavior oriented ways by holding such competencies (Boone, 2019). However, when classifying such competencies in a variety of sectors that is considered important for entrepreneurs, several authors initiate from the fact by taking risk seems to be intrinsic and very important for the success of entrepreneurs. Entrepreneurs can use their competencies that permit them to deal with possible consequences and risk because taking risk open the ways of failure and setbacks (Kraus, 2018). Pull factors of motivation include need for self-determination, achievement, recognition, personal growth, challenges, and profit motive, unemployment, job insecurity, poor pay, lack of alternatives, lack of prospects and innovation are included in the push factors (Cancino, 2020). Previous studies investigated that an individual start their own venture by keeping in view the benefits which can be obtained through pull and push factors of entrepreneurship. Therefore, a person decision about to start a new business is based on pull and push factors of motivation to become an entrepreneur (Kuratko, 2017). The motivation to owning business is depends on the entrepreneurial attitude, subjective norms and entrepreneurship competencies that would become a source of learning and inspiration for other individuals (Izquierdo, 2010). Entrepreneurial role models access the ability of an individual's perception towards environmental support (Lewrick, 2010). Perceived behavioural control, self-efficacy and entrepreneurial motivation can be enhanced by the role models of entrepreneur and this is the result of increasing the possibility to become an entrepreneur (Martiz, 2015).

Entrepreneurship education is required to meet the complications of entrepreneurial phenomenon because entrepreneurship education provides skills, knowledge, and train students to act as an entrepreneur (Jones, 2004). Specific education for particular type of activities is mandatory because the profile of entrepreneurial activity is differing from other profession (Drucker, 2014). Entrepreneurship education should motivate the expansion of attitude, subjective norms and entrepreneurship competencies such as traits, behavior and skills, thus it is necessary that fostering those students to become an entrepreneurs who align themselves with uncertainty, complication and disruption of entrepreneurship atmosphere (Saji \& Nair, 2018).

Entrepreneurial motivation is the procedures that motivate, activate and encourage students to utilize their high level of energies for engage in entrepreneurial activities and accomplishment of entrepreneurial goals (Wilson, 2008). Previous research says that situational variables might also have an explanatory power and the relationship of attitude, subjective norms, and entrepreneurship competencies to entrepreneurship motivation by situational variables is an extant area of research that needs investigation. This research seeks to fill these gaps in the literature and to investigate impact of entrepreneurial motivation among university students via developing psychologically oriented entrepreneurship competencies rather than merely textbook knowledge. Findings of this research will contribute to the literature on cultural and economic contextual dimensions that might also be relevant in uncovering differences. This set of variable 
is limited studied in case of Pakistan hence this study is going to contribute for the literature. It will investigate student's attitudes towards entrepreneurship, which is an important aspect of the economic development of Pakistan. For entrepreneurs especially University students can learn so many things from the findings as it will provide recommendations for their betterment.

\section{Review of Literature}

The literature consists of the economic perspective, theoretical review, and stakeholder's views included entrepreneurship competencies, entrepreneurial motivation and entrepreneurship education. To understand the entrepreneurship is very important for the growth of less developed countries. Many societies have not imparted considerable importance to the entrepreneurship. An individual can engage in entrepreneurial activities through psychological traits (Binks, 2016). Most confident individuals are willing to take risk in order to achieve their entrepreneurial goals. Entrepreneurship creates an effective business structure that is the possibility of wide range of business opportunities for others (Soares, 2013). The one of the main factor of microeconomics is entrepreneur that has been defined in several ways. An entrepreneur makes a business strategy based on economic situation and changing trend of market to run a successful business and achieve their organizational goals (Weilerstone, 2016). An economist who states that entrepreneur is those who have abilities to create a success business stories by converting their new ideas into an efficacious innovation (Lee, 2018). He also state that an entrepreneur always act like as an innovator on which progress, development and growth of economy relied upon him because changing in life encourage to initiate as a powerful individual (Lee, 2018). There are five main features to describe the entrepreneur and discriminate them from others. Reporting five important characteristics that potential entrepreneur always possess are self-efficacy, internal locus of control, pro- activeness, tolerance of uncertainty and need to accomplishment (Herrera, 2018). According to TPB (Kickul, 2018) attitude towards performance refer to the extent in which a person has a positive or negative assessment of the behavior. Generally, the more positive attitude towards the behavior increased the individual's motivation to perform it. Malinda et al, (2018) highlight the necessity to differentiate between general attitudes related to the broad psychological disposition of an individual and domain attitudes indicated to the individual's more precise attitude towards entrepreneurship motivation. Entrepreneurial motivation and change is importance for both researchers and practitioners (Garcia, 2017). Through the understanding of these phenomena we can gain vision in to the entrepreneurial mind. Greater sympathetic of entrepreneurial motivation may provide benefits to teachers, consultants, advisors, and entrepreneurs in terms of envisaging individual tendency and feasibility of entrepreneurship (Zhang, 2017). Understanding how student's motivations, views, goals and perceptions could provide experts and teachers of entrepreneurship greater analytical power of entrepreneurial ability (Belitski, 2017). Ellis, (2019) providing some understanding of the relationship between entrepreneurial motivation and change. Producing understanding about how these phenomena are experienced provides applicable inferences for both consultants and scholars.

Zhu \& Zhang, (2017) investigated the impact of the university environment on entrepreneurial intention. Their study suggested that the lower level of student's formation intention resulted insufficient availability of knowledge related to business and support the procedure of new venture creation energetically. "Furthermore, the modifications in entrepreneurial motivation relative to the individual's opinion of the university atmosphere stronger and significant than the differences with regard to personality traits and socio-economic environmental factors". Successful entrepreneurs have an ability to exploit business opportunities and deploy their resources. The intention to exploit an opportunities may be contemporary, but in order for somebody to take entrepreneurial action, there must be an adequate motivation to do so. From this opinion an individual may have an entrepreneurial skills and traits, but without the connection between intention and action an individual unable to take risk of exploiting those 
opportunities (Zhang, 2017). Motivation is the relationship between intention and action (Malinda, 2018). It can be assumed that without motivation individuals will not engage themselves in entrepreneurial activities. motivation Because motivation gained a lot of attention as the linkage between having certain entrepreneurial features and taking the action of exploiting an opportunities. Motivation is required by the entrepreneurs to engage in organisation formation. This is the one main reason to why an understanding of entrepreneurial motivation has been considered an important area of study.

\section{Proposed Model}

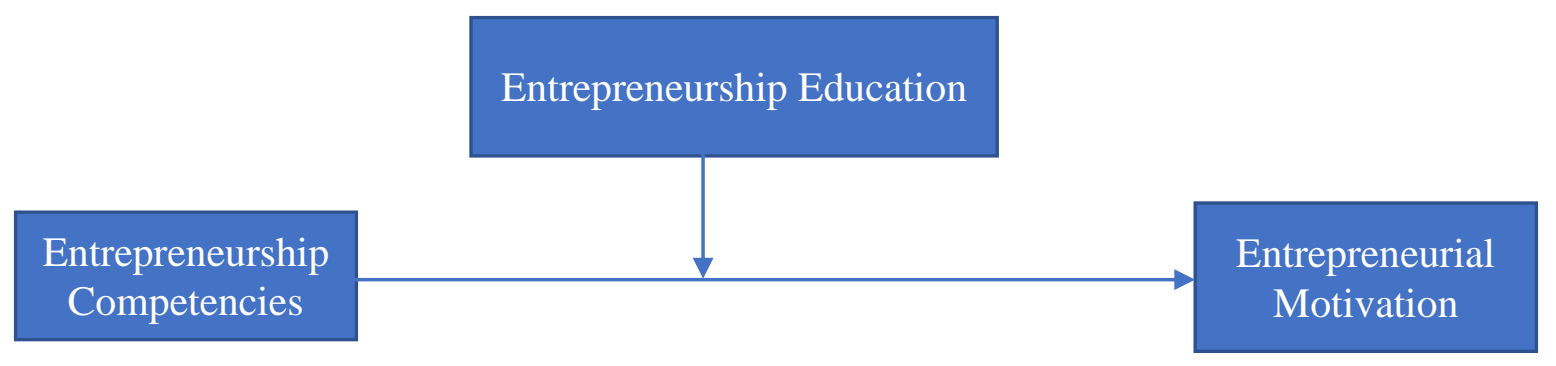

In order to find out the impact on entrepreneurial motivation of entrepreneurship competencies by using the moderating variable (Entrepreneurship Education), the following hypothesis was proposed depending on the objective of the study, theoretical and empirical literature review. Hence, the results from the literature review were used to establish expectations for the relations of the three variables (independent, dependent variable and moderating variable). Therefore, having theoretical and literature reviews in mind the following hypotheses were developed.

H1: "Entrepreneurship Competencies" has a strong positive impact on "entrepreneurship motivation".

H2: "Entrepreneurship Competencies" has a strong positive impact on "entrepreneurship motivation" through "entrepreneurship education" as a moderator.

\section{Methodology}

Quantitative method will be used in this study to explore the relationships among independent, dependent and moderating variables. Questionnaires are based on independent variable Entrepreneurial Competencies, dependent variable that is Entrepreneurial Motivation and Entrepreneurship Education used as moderating variables in this study. The main objective of quantitative approach was to collect information from universities students of Punjab regarding determinants of entrepreneurial motivation with moderating effect of entrepreneurship education. University students enrolled in various degree programs in Punjab are the population of the study. Data is collected through survey questionnaire among different public and private sector universities in Punjab from Faisalabad, Lahore, Multan and Bahawalpur. Almost 390 students of different departments of faculty of management sciences in different universities in Lahore, Faisalabad and Multan, Bahawalpur selected as a sample for this study. Firstly, Approval grant from concerned university department before distributing questionnaires among students to fullup the questionnaires using five-point likert scale. This section contains questions about the respondent's University Title, Gander, Degree Program, Department, Current Semester and CGPA. 40 items scale was used to record responses against entrepreneurship competencies. 21 items was used to record responses against entrepreneurial motivation. 06 items was used to record responses against entrepreneurial motivation. Data analysis was done with the help of (SPSS 22) software. Descriptive statistics is used to signify a data in a meaningful way. Correlation analysis is used to check the relationship among independent, dependent and moderating variable. Linear regression analysis used to analyze links among independent, dependent and mediating variable. 


\section{Results and Discussions}

This section is showing the results of data analysis by using SPSS (22). All variable results of questionnaire like demographic variables, factor analysis, correlation analysis, reliability analysis, simple and multiple regression analysis along with tables are given below.

\section{Demographics analysis}

Demographic characteristics have been analyzed as under:-

Table 1 Gender wise respondents

Total gender wise classification is given under the table.

Gender

\begin{tabular}{|r|l|r|r|r|r|}
\hline \multicolumn{2}{|l|}{} & \multicolumn{1}{|c|}{ Frequency } & \multicolumn{1}{|c|}{ Percent } & Percent & Cumulative Percent \\
\hline & Male & 147 & 52 & 52 & 52 \\
\cline { 2 - 6 } & Female & 137 & 48 & 48 & 100.0 \\
\hline
\end{tabular}

Table 1 showing that the total respondents to conduct the study analysis are 284 in the survey among which 147 are male with $51.85 \%$ proportion and 137 are females with $48.2 \%$ proportion.

Table 2 Respondent's University

\begin{tabular}{|l|r|r|r|r|}
\hline \multicolumn{1}{|l|}{ University } & \multicolumn{1}{|c|}{ Frequency } & \multicolumn{1}{|c|}{ Percent } & Percent & Cumulative Percent \\
\hline \multirow{2}{*}{ GCUF } & 103 & 36.3 & 36.3 & 36.3 \\
\cline { 2 - 5 } GCWUF & 78 & 27.5 & 27.5 & 63.7 \\
\cline { 2 - 5 } BZU & 19 & 6.7 & 6.7 & 70.4 \\
\cline { 2 - 5 } UAF & 34 & 12.0 & 12.0 & 82.4 \\
\cline { 2 - 6 } IUB & 50 & 17.6 & 17.6 & 100.0 \\
\cline { 2 - 6 } TOTAL & 284 & 100.0 & 100.0 & \\
\hline
\end{tabular}

Table 2 shows that the maximum frequency of respondents is 103 from GCUF, 78 respondents are from the GCWUF, 19 respondents are linked with BZU, data collected from UAF consists of 34 respondents and 50 respondents are from the IUB as their valid percentage is $36.3,27.5,6.7$, 12.0 and 17.6 respectively.

Table 3: Educational level

Qualification

\begin{tabular}{|l|r|r|r|r|}
\hline & \multicolumn{1}{|c|}{ Frequency } & \multicolumn{1}{|c|}{ Percent } & Percent & Cumulative Percent \\
\hline \multirow{2}{*}{$\begin{array}{l}\text { Undergraduate } \\
\text { Postgraduate } \\
\text { Total }\end{array}$} & 168 & 59 & 59 & 59 \\
\cline { 2 - 5 } & 116 & 41 & 41 & 100.0 \\
\hline
\end{tabular}

Table 3 showing that the maximum number of respondents is undergraduate and the next portion of respondents are postgraduate. Undergraduate student's strength is 168 which is $59.2 \%$ and the postgraduate students strength is 116 with $40.8 \%$

\section{Table 4: Respondent's Department}

\section{Department}

The table given below provides the information regarding the department,

\begin{tabular}{|l|r|r|r|r|}
\hline & \multicolumn{1}{|c|}{ Frequency } & \multicolumn{1}{|c|}{ Percent } & \multicolumn{1}{|c|}{ Percent } & \multicolumn{1}{|c|}{ Cumulative Percent } \\
\hline \multirow{2}{*}{ Commerce } & 165 & 58.1 & 58.1 & 58.1 \\
\cline { 2 - 5 }
\end{tabular}




\begin{tabular}{|l|r|r|r|r|}
\cline { 2 - 5 } Business Administration & 106 & 37.3 & 37.3 & 95.4 \\
\cline { 2 - 5 } Banking \& Finance & 10 & 3.5 & 3.5 & 98.9 \\
\cline { 2 - 5 } Other & 3 & 1.1 & 1.1 & 100.0 \\
\cline { 2 - 5 } Total & 284 & 100.0 & 100.0 & \\
\hline
\end{tabular}

Table 4 shows that maximum numbers of respondents are from the Commerce department. The numbers of respondents under Commerce Department are 165 with 58.1\%. The second categories of number of respondents under Business Administration Department are 106 and their percentage is 37.3. The third categories of number of respondents under Banking \& Finance Department are 10 with percentage 3.5 . And at the last category, 3 respondents are concerned from other departments with $\%$ age is 1.1

\section{Table 5 Respondent's Semester}

Semester

\begin{tabular}{|l|r|r|r|r|}
\hline & Frequency & Percent & \multicolumn{1}{|c|}{ Percent } & Cumulative Percent \\
\hline $2^{\text {nd }}$ & 43 & 15.1 & 15.1 & 15.1 \\
\cline { 2 - 5 } $4^{\text {th }}$ & 83 & 29.2 & 29.2 & 44.4 \\
$6^{\text {th }}$ & 101 & 35.6 & 35.6 & 79.9 \\
\cline { 2 - 5 } $8^{\text {th }}$ & 57 & 20.1 & 20.1 & 100.0 \\
\hline Total & 284 & 100.0 & 100.0 & \\
\cline { 2 - 5 } & & & \\
\hline
\end{tabular}

Table 5 showing that the frequency of respondents are 43 studying in the $2^{\text {nd }}$ semester, 83 respondents are from the $4^{\text {th }}$ semester, 101 respondents under $6^{\text {th }}$ semester and 57 number of students fall in $8^{\text {th }}$ semester with valid percentage $15.1,29.2,35.6$, and 20.1 respectively.

\section{Table 6 Respondents CGPA}

CGPA

\begin{tabular}{|l|r|r|r|r|}
\hline & $\begin{array}{c}\text { "Frequency } \\
\text { " }\end{array}$ & "Percent" & "Percent" & "Cumulative Percent" \\
\hline $2.5-3.0$ & 60 & 21.1 & 21.1 & 21.1 \\
\cline { 2 - 5 } $3.1-3.5$ & 123 & 43.3 & 43.3 & 64.4 \\
$3.6-4.0$ & 101 & 35.6 & 35.6 & 100.0 \\
\cline { 2 - 5 } Total & 284 & 100.0 & 100.0 & \\
\cline { 2 - 5 }
\end{tabular}

Table 6 illustrates that the 60 respondents out of total 284 respondents having 2.5-3.0 CGPA with $21.1 \%$. The maximum frequency of students is 123 having 3.1-3.5 CGPA and their percentage is 43.3. And the numbers of students' falls in 3.6-4.0 CGPA are 101 with \% age 35.6.

Table 7 Factor Analysis of Entrepreneurship Competencies

\begin{tabular}{|c|c|}
\hline \multicolumn{2}{|l|}{ Factor Analysis of Entrepreneurship Competencies } \\
\hline \multirow{2}{*}{ Entrepreneurship Competencies $(\mathrm{KMO}=.883)$} & Factor \\
\hline & Loading \\
\hline 1. "Motivate people" & .714 \\
\hline 2. "Lead subordinates" & .686 \\
\hline 3. "Determine strategic actions by weighing costs and benefits" & .639 \\
\hline 4. "Organize people" & .628 \\
\hline
\end{tabular}




\begin{tabular}{|c|c|}
\hline $\begin{array}{l}\text { 5. "Be aware of the projected directions of the industry and how changes might } \\
\text { impact the firm" }\end{array}$ & 600 \\
\hline 6. "Delegate effectively" & .595 \\
\hline 7. "Plan the organization of different resources" & .595 \\
\hline 8. "Supervise subordinates" & .588 \\
\hline 9. "Organize resources" & .574 \\
\hline 10. "Actively look for products or services that provide real benefit to customers" & .569 \\
\hline 11. "Plan the operations of the business" & .558 \\
\hline 12. "Prioritize work in alignment with business goals" & .556 \\
\hline 13. "Communicate with others effectively" & .549 \\
\hline 14. "Align current actions with strategic goals" & .542 \\
\hline 15. "Commit to long term business goals" & .538 \\
\hline 16. "Develop long-term trusting relationships with others" & .538 \\
\hline 17. "Keep the organization running smoothly" & .531 \\
\hline 18. "Interact with others" & .500 \\
\hline Cumulative percentage of the variance explained (\%) & 34.328 \\
\hline
\end{tabular}

Table 7 shows the factor analysis of Entrepreneurial competencies. Twenty two (22) items has been excluded from the factor analysis of entrepreneurial competencies. The cumulative 34.328 $\%$ is shown by total variance explained. KMO value is .883 for entrepreneurial competencies which is significant and acceptable. The standard value used for KMO is 0.50 which is considered significant and acceptable.

\section{Table 8 Factor Analysis of Entrepreneurial Motivation}

\begin{tabular}{|c|c|}
\hline \multicolumn{2}{|l|}{ Factor Analysis of Entrepreneurial Motivation } \\
\hline \multirow{2}{*}{ Entrepreneurial Motivation $(\mathrm{KMO}=.849)$} & Factor \\
\hline & Loading \\
\hline 1. "Enables me to get public recognition" & .638 \\
\hline 2. "Allows me to have authority" & .615 \\
\hline 3. "Enables my personal fulfilment" & .586 \\
\hline 4. "Allows me to be my own boss" & .586 \\
\hline 5. "Allows me to afford independence" & .585 \\
\hline 6. "Allows me to get a comfortable life" & .580 \\
\hline 7. "Allows me to ensure a secure future for the family" & .574 \\
\hline 8. "Enables increased funding for retirement" & .543 \\
\hline 9. "Helps me to increase personal income" & .542 \\
\hline 10. "Allows me to have the power to make decisions" & .536 \\
\hline
\end{tabular}




\begin{tabular}{|c|c|}
\hline 11. "Makes it possible to increase opportunities for profit" & .529 \\
\hline 12. "Allows me to participate in the whole decision-making process" & .523 \\
\hline 13. "Allows me to be close to family" & .522 \\
\hline 14. "Allows me to be free" & .522 \\
\hline 15. "Allows me to choose my own tasks" & .521 \\
\hline 16. "Enables me to get monetary compensation based on merit" & .521 \\
\hline 17. "Allows me to face challenges" & .511 \\
\hline Cumulative percentage of the variance explained (\%) & 30.706 \\
\hline
\end{tabular}

Table 8 shows the factor analysis of Entrepreneurial Motivation. Three (03) items has been excluded from the factor analysis of entrepreneurial Motivation. The cumulative $30.706 \%$ is shown by total variance explained. KMO value is .849 for entrepreneurial motivation which is significant and acceptable. The standard value used for KMO is 0.50 which is considered significant and acceptable.

\section{Table 9 Factor Analysis of Entrepreneurship Education}

\begin{tabular}{|c|c|}
\hline Factor Analysis of Entrepreneurship Education & Factor \\
\cline { 2 - 3 } Entrepreneurship Education (KMO=.763) & Loading \\
\hline $1 . \quad$ "used entrepreneurship stories as teaching material” & .700 \\
\hline $2 . \quad$ "guided students to utilize a variety of different experts” & .693 \\
\hline $3 . \quad$ "enabled students to create marketing etc. material for companies" & .689 \\
\hline 4. "guided students how to manage with their money” & .650 \\
\hline 5. "enabled students to create their own company" & .628 \\
\hline 6. "organized / taking part in competition connected to entrepreneur" & .613 \\
\hline Cumulative percentage of the variance explained (\%) & 43.968 \\
\hline
\end{tabular}

Table 9 represents the factor analysis of Entrepreneurship Education. No any item has been excluded from the factor analysis of entrepreneurship education. The cumulative $43.968 \%$ is shown by total variance explained. KMO value is .763 for entrepreneurship education which is significant and acceptable. The standard value used for KMO is 0.50 which is considered significant and acceptable.

Table 10 Descriptive Analysis

Descriptive Statistics

\begin{tabular}{lccccc}
\hline & $\mathrm{N}$ & Minimum & Maximum & Mean & $\begin{array}{c}\text { Std. } \\
\text { Deviation }\end{array}$ \\
\hline $\begin{array}{l}\text { Entrepreneurship } \\
\text { Competencies }\end{array}$ & 283 & 2.11 & 5.00 & 4.2929 & .46392 \\
Entrepreneurial Motivation & 283 & 2.78 & 5.00 & 4.2868 & .44452 \\
Entrepreneurship Education & 284 & 2.00 & 5.00 & 4.2852 & .54141
\end{tabular}


Table 10 shows the results of descriptive statistics of the study variables i.e. entrepreneurial motivation are $2.78,5.00,4.2868$ and .44452 respectively. In the last the values against moderating variable i.e. entrepreneurship education have been found as minimum 2.00, maximum 5.00, mean value 4.2852 and standard deviation .54141

\section{Table 11 Correlation among Independent, Dependent and Moderating variables}

\begin{tabular}{lccc}
\hline Variable & $\begin{array}{c}\text { Entrepreneurial } \\
\text { Competencies }\end{array}$ & $\begin{array}{c}\text { Entrepreneurial } \\
\text { Motivation }\end{array}$ & $\begin{array}{c}\text { Entrepreneurship } \\
\text { Education }\end{array}$ \\
\hline $\begin{array}{l}\text { Entrepreneurship } \\
\text { Competencies }\end{array}$ & 1 & $.654^{* *}$ & $.646^{* *}$ \\
Entrepreneurial Motivation & 1 & $.638^{* *}$ \\
Entrepreneurship Education & & 1
\end{tabular}

Entrepreneurial motivation has positive correlation of .654 with entrepreneurship competencies. The value of correlation between these variables shows the significant and direct relationship. Increase in entrepreneurial competencies will also be the result of increase in entrepreneurial motivation. The moderating variable (Entrepreneurship Education) has a positive relationship with dependent variable (Entrepreneurial Motivation) as shown by the value is .638. The value of Correlation between entrepreneurship education and entrepreneurial motivation shows that increase in entrepreneurial motivation is the result of increase in entrepreneurship education. So there is a significant and direct relationship between these variables.

\section{Table 12 Reliability Analysis}

Cronbach alpha Values
\begin{tabular}{|c|c|c|c|}
\hline Variable & Nature of Variable & No of Items & Cronbach alpha Value \\
\hline $\begin{array}{c}\text { Entrepreneurship } \\
\text { Competencies }\end{array}$ & Independent Variable & 18 & .886 \\
\hline $\begin{array}{c}\text { Entrepreneurial } \\
\text { Motivation }\end{array}$ & Dependent Variable & 18 & .864 \\
\hline $\begin{array}{c}\text { Entrepreneurship } \\
\text { Education }\end{array}$ & Moderating Variable & 06 & .743 \\
\hline
\end{tabular}

The above table shows the Cronbach values of all variables independent variables i.e. Entrepreneurship Competencies, dependent variable i.e. Entrepreneurial Motivation and Entrepreneurship Education which is the moderator are $.886, .864$ and .743 respectively. It means that instruments are reliable.

\section{Regression Analysis}

In order to check the influence of entrepreneurship competencies the simple regression analysis technique has been run through SPSS. Here entrepreneurship competencies are independent and entrepreneurial motivation is dependent variable.

Table 13 Model Summary 


\begin{tabular}{|l|r|r|r|r|}
\hline Model & \multicolumn{1}{|c|}{ R } & \multicolumn{1}{|c|}{ R Square } & \multicolumn{1}{|c|}{ Adjusted R Square } & \multicolumn{1}{|c|}{$\begin{array}{c}\text { Std. Error of the } \\
\text { Estimate }\end{array}$} \\
\hline 1 & $.654^{\mathrm{a}}$ & .428 & .426 & .33632 \\
\hline
\end{tabular}

a. Predictors: (Constant), AVGEC

The value of Adjusted R Square in this table is .42 while the value of R-Square is .428 which shows the difference between entrepreneurship competencies and entrepreneurial education. As value is .428 it can be interpreted as entrepreneurial competencies is explaining $42.8 \%$ of variation in entrepreneurial motivation.

Table 14 ANOVA ${ }^{\mathrm{a}}$

\begin{tabular}{|l|l|r|r|r|r|r|}
\hline \multicolumn{2}{|l|}{ Model } & Sum of Squares & \multicolumn{1}{c|}{ df } & Mean Square & \multicolumn{1}{c|}{ F } & \multicolumn{1}{c|}{ Sig. } \\
\hline \multirow{3}{*}{1} & Regression & 23.667 & 1 & 23.667 & 209.242 & $.000^{\mathrm{b}}$ \\
\cline { 2 - 7 } & Residual & 31.671 & 280 & .113 & & \\
\cline { 2 - 8 } & Total & 55.338 & 281 & & & \\
\hline
\end{tabular}

a. Dependent Variable: AVGEM

b. Predictors: (Constant), AVGEC

ANOVA table value of $\mathrm{F}=209.242$ along with its significance value of $\mathrm{p}=.000$ indicating higher level of model fitness.

\begin{tabular}{|c|c|c|c|c|c|c|}
\hline \multicolumn{7}{|c|}{ Table 15 Coefficients ${ }^{a}$} \\
\hline \multicolumn{2}{|c|}{ Model } & \multicolumn{2}{|c|}{ Unstandardized Coefficients } & \multirow{2}{*}{$\begin{array}{c}\text { Standardized } \\
\text { Coefficients }\end{array}$} & \multirow[t]{2}{*}{$\mathbf{t}$} & \multirow[t]{2}{*}{ Sig. } \\
\hline & & B & Std. Error & & & \\
\hline \multirow{2}{*}{1} & (Constant) & 1.605 & . 187 & & 8.598 & .000 \\
\hline & AVGEC & .625 & .043 & .654 & 14.465 & .000 \\
\hline
\end{tabular}

a. Dependent Variable: AVGEM

In this coefficient table the values of $p, t$ and $\beta$ as $P<.000), t=14.465$ and $\beta=.625$. The value of $\beta$ is .625 shows that one unit change in entrepreneurial competencies will cause .625 unit change in entrepreneurial motivation.

\section{Multiple Regression}

Table 16 Model Summary

\begin{tabular}{|l|r|r|r|r|}
\hline Model & R & R Square & Adjusted R Square & Std. Error of the Estimate \\
\hline 1 & $.654^{\mathrm{a}}$ & .428 & .426 & .33632 \\
\hline 2 & $.713^{\mathrm{b}}$ & .509 & .505 & .31211 \\
\hline
\end{tabular}

a. Predictors: (Constant), AVGEC

b. Predictors: (Constant), AVGEC, AVGEE

In model 1 the value of Adjusted R Square in this table is .426. The value of R-Square is .428 
which shows the difference between entrepreneurship competencies and entrepreneurial education. As value is .428 it can be interpreted as entrepreneurial competencies is explaining $42.8 \%$ of variation in entrepreneurial motivation. While in model 2 the value of Adjusted R Square in this table is .505. The value of R-Square is .509 which shows the difference between entrepreneurship competencies and entrepreneurial education. As value is .509 it can be interpreted as entrepreneurial competencies is explaining $50.9 \%$ of variation in entrepreneurial motivation.

Table 17 ANOVA $^{\mathrm{a}}$

\begin{tabular}{|l|l|r|r|r|r|r|}
\hline \multicolumn{2}{|l|}{ Model } & Sum of Squares & \multicolumn{1}{c|}{ df } & Mean Square & \multicolumn{1}{c|}{ F } & Sig. \\
\hline \multirow{4}{*}{1} & Regression & 23.667 & 1 & 23.667 & 209.242 & $.000^{\mathrm{b}}$ \\
\cline { 2 - 7 } & Residual & 31.671 & 280 & .113 & & \\
\cline { 2 - 7 } & Total & 55.338 & 281 & & & \\
\hline \multirow{3}{*}{2} & Regression & 28.159 & 2 & 14.080 & 144.535 & $.000^{\mathrm{c}}$ \\
\cline { 2 - 7 } & Residual & 27.179 & 279 & .097 & & \\
\cline { 2 - 7 } & Total & 55.338 & 281 & & & \\
\hline
\end{tabular}

a. Dependent Variable: AVGEM

b. Predictors: (Constant), AVGEC

c. Predictors: (Constant), AVGEC, AVGEE

In model 1 value of $\mathrm{F}$ is 209.242 and its $\mathrm{p}$ value is .000 which shows a significance of model. In model 2 value of $F$ is 144.535 with $p$ is .000 . Both the models are significant.

\begin{tabular}{|c|c|c|c|c|c|c|}
\hline \multicolumn{7}{|c|}{ Table 18 Coefficients ${ }^{a}$} \\
\hline \multirow{2}{*}{\multicolumn{2}{|c|}{ Model }} & \multicolumn{2}{|c|}{ Unstandardized Coefficients } & \multirow{2}{*}{$\begin{array}{c}\begin{array}{c}\text { Standardized } \\
\text { Coefficients }\end{array} \\
\text { Beta } \\
\end{array}$} & \multirow[t]{2}{*}{$\mathrm{t}$} & \multirow[t]{2}{*}{ Sig. } \\
\hline & & B & Std. Error & & & \\
\hline \multirow{2}{*}{1} & (Constant) & 1.605 & .187 & & 8.598 & .000 \\
\hline & AVGEC & .625 & .043 & .654 & 14.465 & .000 \\
\hline \multirow{3}{*}{2} & (Constant) & 1.286 & .179 & & 7.166 & .000 \\
\hline & AVGEC & .395 & .052 & .413 & 7.525 & .000 \\
\hline & AVGEE & .305 & .045 & .373 & 6.791 & .000 \\
\hline
\end{tabular}

The above table shows regression coefficients, values of $p, t$ and $\beta$. In model 1 the value of Beta is .625 and the value of $t$ is 14.465 and $p$ value is .000 . In model 2 the value of $p, t$ and $\beta$ for independent and moderating variable as:

$\begin{array}{cc}\text { Independent variable } & \text { Moderating variable } \\ \mathrm{P}<.000) & \mathrm{P}<.000) \\ \mathrm{t}=7.525 & \mathrm{t}=6.791 \\ \beta=.395 & \beta=.305\end{array}$

$\beta$ (coefficient) is used to give prediction of change in dependent variable due to one unit change in independent variable. The $\beta$ value in $2^{\text {nd }}$ model is .395 and it shows that one unit change in entrepreneurial competencies will cause .395 unit changes in the dependent variable .i.e. entrepreneurial motivation. Further $\beta$ value of (unstandardized coefficient) against entrepreneurship education shows one unit change in entrepreneurship education will bring .305 units change in dependent variable (Entrepreneurial Motivation). 


\section{Findings}

Entrepreneurship competencies that are considered very important for entrepreneurs have been found here positive relationship with the entrepreneurial motivation. Simply increase in the entrepreneurship competencies will increase the entrepreneurial motivation. So the impact of entrepreneurship competencies on entrepreneurial moderation with entrepreneurship education is found significant. To enhance the students' entrepreneurial motivation, the education and training should emphasize the growth of students' psychological and social skills related to entrepreneurship by casing not only the rational length, but specially the expressive dimension and critical rational. In terms of the entrepreneurship competencies several researchers discussed in previous studies. Spencer \& Spencer, (1993) reported that competencies are the basic features of an individuals related to the great performance in a job and can be mutual across circumstances. Base on the entrepreneurial competencies several researchers argued and the most inclusive source list is delivered by (Mitchelmore and Rowley, 2010). The structure of entrepreneurial competencies signifies the theoretical view about the entrepreneurial competencies. Criteria are suggested by entrepreneurs, professionals and research scholars must be considered in designing entrepreneurial competencies matrix. Universities all over the world established to supply the market requirements for polished entrepreneurs and offered a several entrepreneurship learning programs pursuing the main objectives to teach the individuals who will be able to apply the entrepreneurial skills and attitudes.

\section{Conclusion and Recommendations}

This investigation proved that the impact of entrepreneurial competencies in this study has been found in greater strength as compared to the other factors such as attitude and subjective norms. From the above findings it can be concluded that entrepreneurship competencies has significant impact on entrepreneurial motivation. Additionally entrepreneurial education has moderated the relationship of independent variables and dependent variable (entrepreneurial motivation). Here entrepreneurial education has been strengthening the relationship between entrepreneurial competencies and entrepreneurial motivation. In the presence of entrepreneurial education the impact of all independent variables was augmented up to a great strength. Keeping in view the above situation it is recommended that educational institutes should focus on entrepreneurial education in order to promote entrepreneurial culture.

\section{Limitations}

This research like other researches also has some limitations. The first limitation of this study is cross sectional nature. Data is cross sectional and on the basis of this cause and effect relationship cannot be concluded. Further a limited number of universities were approached for data collection. And overall population has not been approached for data collection. Another limitation attached to this study is small sample size. The sample size is small and larger sample size may yield different results. Additionally data was collected only from the enrolled students who don't have any practical experience related to entrepreneurial activates. In addition to this the impact of gender was not explored in this study. Gender differences may yield different results.

\section{Future Directions}

This study also presents some potential areas to be explored in future. First of all in future researches could be conducted by collecting data from a large sample size. Future research could examine this study for mixed gender with more heterogeneous sample. A qualitative study may provide deeper insights. This research was cross-sectional in nature. In future, longitudinal research may reveal more detailed and in-depth results. Only a few number of variables have been tested in this study, in future research different sets of variable combinations could be used. The study used independent variables, a dependent variable and a moderator. Future research could be conducted by exploring some other mediators and moderators to understand the 
phenomenon between independent and dependent more deeply.

\section{References}

Belitski, M., \& Heron, K. (2017). Expanding entrepreneurship education ecosystems. Journal of Management Development.

Binks, M., Starkey, K., \& Mahon, C. L. (2016). Entrepreneurship education and the business school. Technology Analysis \& Strategic Management, 18(1), 1-18.

Boone, C., Lokshin, B., Guenter, H., \& Belderbos, R. (2019). Top management team nationality diversity, corporate entrepreneurship, and innovation in multinational firms. Strategic management journal, 40(2), 277-302.

Bouncken, R., Ratzmann, M., Barwinski, R., \& Kraus, S. (2020). Coworking spaces:

Empowerment for entrepreneurship and innovation in the digital and sharing economy. Journal of Business Research, 114, 102-110.

Bu, J., \& Cuervo-Cazurra, A. (2020). Informality costs: Informal entrepreneurship and innovation in emerging economies. Strategic Entrepreneurship Journal, 14(3), 329-368.

Cancino, C. A., Merigó, J. M., Urbano, D., \& Amorós, J. E. (2020). Evolution of the entrepreneurship and innovation research in Ibero-America between 1986 and 2015. Journal of Small Business Management, 1-31.

Drucker, P. (2014). Innovation and entrepreneurship. Routledge.

Ellis, V., Steadman, S., \& Trippestad, T. A. (2019). Teacher education and the GERM: Policy entrepreneurship, disruptive innovation and the rhetorics of reform. Educational Review, 71(1), 101-121.

Galvin, P., Burton, N., \& Nyuur, R. (2020). Leveraging inter-industry spillovers through DIY laboratories: Entrepreneurship and innovation in the global bicycle industry. Technological Forecasting and Social Change, 160, 120235.

Garcia, D. H., Leles, A. D., \& Romano, R. R. (2017). Program entrepreneurship and innovation: education as the core of innovation. In Advances in The Human Side of Service Engineering (pp. 235-244). Springer, Cham.

Hilson, G., \& Maconachie, R. (2020). Entrepreneurship and innovation in Africa's artisanal and small-scale mining sector: Developments and trajectories. Journal of Rural Studies, 78, 149-162.

Herrera, F., Guerrero, M., \& Urbano, D. (2018). Entrepreneurship and innovation ecosystem's drivers: the role of higher education organizations. In Entrepreneurial, innovative and sustainable ecosystems (pp. 109-128). Springer, Cham.

Izquierdo, E., \& Deschoolmeester, D. (2010). What entrepreneurial competencies should be emphasized in entrepreneurship and innovation education at the undergraduate level. Handbook of research in entrepreneurship education, 3, 194-207.

Jones, C., \& English, J. (2004). A contemporary approach to entrepreneurship education. Education+ training.

Kickul, J., Gundry, L., Mitra, P., \& Berçot, L. (2018). Designing with purpose: advocating innovation, impact, sustainability, and scale in social entrepreneurship education. Entrepreneurship Education and Pedagogy, 1(2), 205-221.

Kraus, S., Ribeiro-Soriano, D., \& Schüssler, M. (2018). Fuzzy-set qualitative comparative analysis (fsQCA) in entrepreneurship and innovation research-the rise of a method. International Entrepreneurship and Management Journal, 14(1), 15-33.

Kuratko, D. F. (2017). Corporate entrepreneurship \& innovation: Today's leadership challenge. The Wiley handbook of entrepreneurship, 293-311.

Lee, R. M., \& Yuan, Y. S. (2018). Innovation education in China: Preparing attitudes, approaches, and intellectual environments for life in the automation economy. In Higher education in the era of the fourth industrial revolution (pp. 93-119). Palgrave Macmillan, Singapore. 
Lewrick, M., Omar, M., Raeside, R., \& Sailer, K. (2010). Education for entrepreneurship and innovation:"Management capabilities for sustainable growth and success". World Journal of Entrepreneurship, Management and Sustainable Development

Malinda, M. (2018). Effectiveness of entrepreneurship and innovation learning methods. Case study at Universitas Kristen Maranatha, Bandung, Indonesia. International Journal of Business and Administrative Studies, 4(3), 122-128.

Maritz, A., \& Donovan, J. (2015). Entrepreneurship and innovation: Setting an agenda for greater discipline contextualisation. Education+ Training.

Saji, B. S., \& Nair, A. R. (2018). Effectiveness of innovation and entrepreneurship education in UAE higher education. Academy of Strategic Management Journal, 17(4), 1-12.

Si, S., Ahlstrom, D., Wei, J., \& Cullen, J. (2020). Business, entrepreneurship and innovation toward poverty reduction.

Soares, F. O., Sepúlveda, M. J., Monteiro, S., Lima, R. M., \& Dinis-Carvalho, J. (2013). An integrated project of entrepreneurship and innovation in engineering education. Mechatronics, 23(8), 987-996.

Weilerstein, P., \& Byers, T. (2016). Guest editorial: Entrepreneurship and innovation in engineering education. Advances in Engineering Education, 5(1), 1-9.

Wilson, K. E. (2008). Entrepreneurship education in Europe. Entrepreneurship and higher education.

ZHANG, S. L., \& ZHENG, X. Q. (2017). Separation and Integration of Professional Education, Innovation Education and Entrepreneurship Education-Based on the Perspective of "Triple Helix" Theory. Heilongjiang Researches on Higher Education, 06.

Zhu, H. B., Zhang, K., \& Ogbodo, U. S. (2017). Review on innovation and entrepreneurship education in Chinese universities during 2010-2015. Eurasia Journal of Mathematics, Science and Technology Education, 13(8), 5939-5948. 